\title{
The Idea of a New Zimbabwe Post-Mugabe
}

\author{
Sylvester Marumahoko and Tinashe C. Chigwata
}

\section{INTRODUCTION}

Zimbabwe has gone through deep political, economic and social challenges for close to three decades. Once known as the shining light of Africa, Zimbabwe is now often known for dominating international headlines for the wrong reasons. In November 2017, the country experienced a radical change to the constitutional and political order, which brought an end to former President Robert Mugabe's 37-year reign. Emmerson Mnangagwa, who was once Mugabe's right-hand man, assumed leadership of both the country and the ruling Zimbabwe African National Union-Patriotic Front (ZANU-PF). He was reelected in the July 2018 harmonised elections, although under disputed circumstances. The removal of Robert Mugabe has provided the country an opportunity to

\footnotetext{
S. Marumahoko $(\bowtie)$

School of Post Graduate Studies (Research and Innovation), University of Johannesburg, Auckland Park, South Africa
}

T. C. Chigwata

Dullah Omar Institute for Constitutional Law, Governance and Human Rights, University of the Western Cape, Bellville, South Africa

e-mail: tchigwata@uwc.ac.za

(C) The Author(s) 2020

S. J. Ndlovu-Gatsheni, P. Ruhanya (eds.), The History and Political

Transition of Zimbabwe, African Histories and Modernities, https://doi.org/10.1007/978-3-030-47733-2_13 
break from the past, and hopes have been raised for the birth of a new Zimbabwe. This chapter explores some of the measures that the administration post-Mugabe should implement to set the country on a new path. Thus, the purpose of this chapter is not to argue for a particular political formation or political leaders to govern. Rather, its objective is to explore whether the idea of a new Zimbabwe is possible and what it would take to realise this objective. Before discussing the prospects for this desired state of affairs, it is important to examine the current situation, which is explored in the first part of the chapter. A brief overview of the fall of Mugabe and rise of Mnangagwa is then provided to show how a leader who commanded respect beyond the shores of our continent could exit in such an undignified manner. The core section is dedicated to a discussion of the prospects for a new Zimbabwe, and concluding remarks end the chapter.

\section{The Zimbabwean 'Problem'}

The Zimbabwean problem is multifaceted, including economics, governance, politics and humanitarian issues (Ndlovu-Gatsheni 2003: 124). The problem is attributed to different sources, depending on where one is sitting or whose interests one serves. The colonial legacy, including the authoritarian colonial state and its institutions, as well as its policies, which significantly damaged the well-being of the black population, is often cited as one of the sources of this problem (Muzondidya 2009: 167-168). Raftopoulos (2009: 201) attributes the Zimbabwean problem partially to the political legacies of African nationalist politics. Imperialism, including the restrictive measures (perceived by some as sanctions) imposed on Zimbabwe by western countries, is often cited by the ruling party and its sympathisers as the major source of the problem (Government of Zimbabwe 2013: 8). On the other hand, another group, largely constituted by the opposition, some western countries, a section of civic society and some scholars, attributes the Zimbabwean crisis to the ruling elite in ZANU-PF. They often cite bad policies, corruption and economic mismanagement by ZANU-PF as some of the major causes. Putting this blame game aside, it is clear that the Zimbabwean problem is the outcome of a variety of factors. Ndlovu-Gatsheni (2003: 100) argues that the contribution of the ruling elite to the problem should not be ignored. What was its contribution to the Zimbabwe problem and how did the problem evolve? 
Zimbabwe attained independence in 1980 after a protracted armed resistance against British colonial rule. A constitution negotiated at Lancaster House by the British government, Rhodesian minority government and the liberation movements paved the way for independence (Marumahoko 2018: 16). While conserving white freedoms and benefits, the Constitution provided a foundation for constitutionalism in postcolonial Zimbabwe by, among other things, guaranteeing individual rights, the independence of the judiciary and multiparty democracy (Muzondidya 2009: 172). The first democratic elections of 1980, held under the regime of the Lancaster House Constitution, were won by the Zimbabwe African National Union (ZANU) party under the leadership of Robert Mugabe. Bourne (2011: 103) argues that ZANU was 'structured as a Marxist party, with a politburo, and top-down organization reflecting the tenets of "democratic centralism"'. He further contends that "Mugabe was highly dependent on the military leaders' of the Zimbabwe African National Liberation Army, the military wing of ZANU during the liberation struggle. These leaders continued to play a critical role during Mugabe's days in power, and they ultimately shaped his removal close to three decades later. The ZANU-led government adopted a development paradigm that centred on rehabilitation, reconstruction and resettlement. A number of pro-poor policies were adopted, which impacted positively on the delivery of public and social sectors such as education, health and sanitation (Muzondidya 2009: 168-169; Bourne 2011: 111). Boosted with political power and a strong economy, backed by productive agriculture, mining and manufacturing, the government had the necessary instruments to transform the lives of the majority of Zimbabweans who were at the receiving end of colonial policies. The period 1980-1990 is generally regarded as a decade of social progress.

While advancing welfare programmes, ZANU did not lose sight of the need to entrench its power amid the strong competition that was coming from the Joshua Nkomo-led Zimbabwe African People's Union (ZAPU) party. The Prime Minister's Directives on Decentralisation of 1984 and 1985, which provided for the establishment of various vertical state organisation structures, were used by ZANU to consolidate its hold on political power. The roles of the party and state were fused through bodies that were formed according to these Directives (Muzondidya 2009: 178; Bourne 2011:218). At around the same time, a confrontation with ZAPU took place in the Matabeleland provinces and some parts of Midlands, ZAPU's strongholds. The military deployment to solve what Muzondidya 
refers to as a 'political problem' in these provinces, dominated by Ndebelespeaking people, resulted in the loss of human life and property (Muzondidya 2009: 179, 185). Peace was restored when ZAPU merged with ZANU in 1987 to form ZANU-PF under an agreement called the Unity Accord. This effectively ended competitive politics, so the political hegemony of ZANU-PF was unchallenged. As a result, and according to some scholars, Zimbabwe became de facto a one party state, where opposition and criticism had no role (Bourne 2011: 120; Ndlovu-Gatsheni 2003: 118). The appetite of some of the ruling elite not just for political power but also for private accumulation grew. Corruption cases of a grand nature that rocked the country, such as the Willowgate Scandal of 1988, attest to this. Constitutional amendments that were instituted towards the end of the first decade of independence ensured that the executive, in particular the President, could not be effectively checked by oversight institutions such as parliament.

In the second decade of independence, 'many things began to go seriously wrong', overshadowing positive developments in the country (Bourne 2011: 126). The foundation for this situation had been set in the first decade. Corruption became widespread, poverty deepened, politics of patronage began to flourish, and labour strikes and food riots became the order of the day (Raftopoulos 2009: 203-204). The World Bank-backed Economic Structural Adjustments Programme (ESAP), which the government adopted in the 1990s, failed to arrest the deteriorating economic and social situation (Muzondidya 2009: 188). Instead, owing to market liberalisation, privatisation and the reduction of government expenditure through the removal of government subsidies on food, health and education, the socio-economic gains recorded in the first decade began to be eroded. People lost their jobs, prices rocketed, companies closed and corruption gained momentum. It was no wonder that ESAP was nicknamed 'Extreme Suffering for African People' (Bourne 2011: 127). NdlovuGatsheni (2003: 122) argues that the adoption of ESAP not only proved that the ZANU-PF government had abandoned the people but also that the political leadership, which had proclaimed itself socialist at independence, had easily turned capitalist. Conversely, Bourne (2011: 127) claims that the regime's attitude towards limiting the landscape for political participation, especially from opposition parties and alternative sources of power, did not change. Legislative amendments, incentives and sanctions were some of the many strategies that were utilised towards this end (Ndlovu-Gatsheni 2003: 123). However, with the right political and 
economic direction, this state of affairs could have been rescued as the economy had not reached the life support stage. The ingredients for a fullblown crisis were brewing as Zimbabwe approached the new millennium (Raftopoulos 2009: 201-203). Disagreeing with the direction that ZANU-PF was taking, the Movement for Democratic Change (MDC) was formed in 1999 from a conglomeration of labour, student and civic groups. The party, which mobilised on democratic principles, would later drive ZANU-PF to the limit, forcing the ruling party to embark on drastic measures to stay in power. The opposition was easily branded a creation of the west and an enemy of the state that needed to be extinguished by whatever means possible.

The third decade of independence is often described as the crisis decade, when the political and economic situation spilled out of control. Key questions around the role of the state, land and property rights, political and civil liberties, economic direction and the central role of the former President, Robert Mugabe, came to the forefront (Raftopoulos 2009: 201). Raftopolous (2009: 202) contends that ZANU-PF 'drew on a combination of revived nationalism that privileged its role in the liberation of the country, prioritized the centrality of the fight for land, and demonized all those outside the selective "patriotic history" it espoused'. It adopted the Fast Track Land Reform Programme in early 2000, under which land in the hands of white farmers was taken without compensation and redistributed to blacks as a way of addressing inequalities in land ownership. Britain and some other western countries responded by imposing restrictions on Zimbabwe, as they considered the programme to be an unlawful deprivation of property rights. ZANU-PF has argued since then that these are not restrictions but actually illegal economic sanctions that hurt ordinary citizens the most (Government of Zimbabwe 2013: 8, 12). The question of whether these are restrictions or sanctions again depends on which side of the fence one is sitting on. What is not in dispute is that, after the programme was imposed in the early 2000s, the economy, which was already struggling, descended to crisis levels characterised by hyperinflation, low agricultural and industrial productivity, a ballooning informal sector and a gross domestic product that had shrunk by $50 \%$ as of 2008 (Government of Zimbabwe 2013: 8).

Facing an international barrage of criticism regarding its human rights record, among other issues, Zimbabwe walked out of the Commonwealth in 2003. Relations with other international organisations and multilateral finance institutions soured, marking the beginning of Zimbabwe's 
international isolation. With the MDC posing a serious threat to ZANUPF's political hegemony, especially after taking control of urban local government, Ndlovu-Gatsheni (2003: 104) contends that 'regime security was often given priority at the expense of human security'. Bourne (2011: 162) establishes that the 'state could no longer provide many of its citizens with food, basic services, a guaranteed rule of law, and socio-economic as well as civil and political rights'. Gubbay (2016: 13) notes that the effectiveness and independence of the judiciary, the bedrock of the rule of law and constitutionalism were compromised in many respects. The failure by the judiciary and parliament to effectively exercise their designated constitutional role facilitated the abuse of executive power (Hatchard et al. 2004: 314). The Government of National Unity (GNU), established in 2009 and constituted by ZANU-PF and the two MDC formations, following the disputed elections of 2008 , rescued this situation.

The fourth decade of independence began when Zimbabwe was being governed by the GNU. The GNU managed to stabilise the political and economic situation as food, among other things, began to be more widely available in shops. The adoption of a multicurrency regime anchored on the United States (US) dollar contained inflation. Public service delivery in areas such as water, sanitation, health and education improved (Bourne 2011: 226). The GNU also successfully steered the adoption of the first home-grown Constitution, which is pregnant with promise for a better life for ordinary citizens. The adoption of the new Constitution did not solve the Zimbabwean problem, however. Soon after the 2013 harmonised elections, which were won by ZANU-PF and brought an end to the GNU's tenure, the situation began to regress. The stagnant economy, which is perhaps the biggest challenge confronting the political leadership in Zimbabwe since the 2013 elections, shows that it takes more than electoral votes, whether genuinely acquired or not, to fix bread and butter issues. The developments after the removal of Robert Mugabe from office in November 2017, to be discussed in the next section, support this thesis.

\section{The Fall of Mugabe and the Rise of Mnangagwa}

On 21 November 2017, President Robert Mugabe handed in his resignation letter to Jacob Mudenda, the Speaker of the National Assembly. Earlier on, the military had taken over the country and confined the President to his residence, claiming that it had been forced to intervene in civilian affairs in order 'to pacify a degenerating political, social and 
economic situation in [Zimbabwe] which if not addressed may result in violent conflict' (Jordan 2017: 1). Its publicly stated objective was to 'address the human security threats in the country' (Jordan 2017: 1; Jongwe 2018: 1).

The events that culminated in Mugabe's resignation were welcome for some while for others they were unacceptable and frightening in a constitutional democracy. Whichever side one is on, the question that begs an answer is whether the events fall into the narrative of a national democratic project or a military takeover. Some say the events had no bearing as the president voluntarily gave notice of his resignation in terms of section 96 (1) of the Constitution of Zimbabwe (Huffingtonpost 2017: 1; VOA 2017: 1). In democracies, leaders leave office when they have lost the support of the people. The president's departure from office was endorsed by the leaders of the opposition, ordinary citizens and the international community. However, the status of the departure was cast wide open when Mugabe later made an about-turn and insinuated that a military coup, and not voluntary resignation, was the reason he vacated office so suddenly. This has prompted some to reexamine the circumstances.

It seems there are merits to Mugabe's claim that he left office owing to a military coup. His ousting had some of the characteristics of coups seen across the world, although it was celebrated by citizens and was not criticised by the international community. First, the army moved tanks and other military vehicles and gun-wielding soldiers to strategic places around the country, which is often the case when mounting a military coup. The parliament building was barricaded, the police disarmed and the president confined to his residence. Secondly, the military placed some of Mugabe's ministers and strong supporters under house arrest. Thirdly, a senior military official broadcast live on radio and television, reassuring citizens that the military had not seized political power but were taking measures to restore normality in accordance with the Constitution.

The Constitution of Zimbabwe vests the power to deploy the military in the President and not the army commanders, as happened during the measures that culminated with Mugabe's ousting. In addition, there are special circumstances under which the army can be moved from the barracks. One of these circumstances relates to disasters. In this case, however, there was no disaster to attend to, nor was there a humanitarian crisis. The country was not at war with a foreign power and parliament had not approved the deployment of the army. 
A related question is why the events were happening 37 years after independence, and where they were taking the country. It has been suggested that one of the reasons that explains Mugabe's unceremonious departure from office is that he had lost the support of the army and the influential war veterans that had propped up his rule for close to four decades (Kwaramba 2017: 1; Rupiya 2012: 13). Another reason is perhaps that Mugabe had incensed the army and the war veterans by procrastinating about the question of who would succeed him in the party and government. This saw the emergence of two factions in ZANU-PF, the so-called G40 and Lacoste factions, each vying to take over (Chirimambowa 2016: 1).

The situation was compounded by the emergence of Grace Mugabe, the first lady, as a formidable voice in the ruling party, close or working with the G40 factions. She appeared to have sidelined the war veterans and the commanders of the army, who were historically considered the vanguard of the ruling party (Chirimambowa 2016: 2; Kwaramba 2017: 1). Mugabe helped to seal his own fate by appearing to suggest that he would prefer his wife to take over from him. This brought him into conflict with the army and the war veterans who preferred Emmerson Mnangagwa, one of Mugabe's vice-presidents. In the end, Mugabe lost the battle to shape the succession debate.

There are a few lessons that can be drawn from this. One of them is about the danger of concentrating too much power in one person at the expense of institutions. Another is that sitting presidents need to avoid overstaying their welcome. Yet another is that leadership should always change hands. It should be acknowledged, however, that not everything about Mugabe was bad. The strong education system that Zimbabwe is often acclaimed for is largely attributed to ZANU-PF policies and Mugabe in particular. The idea of land reform, which many criticise Mugabe for, was not bad in itself, but it could have been handled better. Finally, Mugabe cannot be blamed for everything that has gone wrong in Zimbabwe. All Zimbabweans, particularly those who were governing with him, must take equal blame and acknowledge their mistakes and wrongdoing. Even ordinary citizens must take a portion of the blame: it is often said that the people deserve the government they every nation has the government it deserves. History the world over has proved that people power can remove governments that no longer serve their interests. Even so, the removal of Mugabe may have been necessary, but did it mark the beginning of a new era for Zimbabwe? 
With Mugabe gone, his former vice-president and close collaborator, Emmerson Mnangagwa, took the reins of power in both the government and the ruling party in November 2017. He announced himself on the political scene as a reformist who was prepared to redefine the political and economic trajectory of the country. He nonetheless appointed a cabinet that primarily constituted ministers from the previous government to take charge until the July 2018 harmonised elections, raising early questions about his intentions to change. He declared that 'Zimbabwe is Open for Business' and initiated the process of international reengagement. President Mnangagwa introduced a raft of measures, which included anticorruption initiatives, to ensure effective, clean and accountable government. The political environment improved, to the extent that opposition political parties largely freely mobilised. Even though the electoral environment improved in general, the question remains whether this improvement was enough to guarantee an undisputed election outcome. The outcome of the July 2018 harmonised elections, in which Mnangagwa was reelected, was disputed by the MDC, giving rise to a legitimacy deficit.

In his inauguration speech, Mnangagwa declared the 'dawn of the "Second Republic" in Zimbabwe. The stated strategic vision of Mnangagwa's government was for Zimbabwe to become a middle-income country by 2030 . He initially appointed a refreshed cabinet and retired a number of senior bureaucrats who had been in government for decades. The government announced a number of reforms to address the economic challenges. However, ever since his reelection on 30 July 2018, the economy is threatening to descend to the 2008 crisis levels with clear indications that the market lacks confidence and trust in the new government. Prices are rocketing, fuel is in short supply and companies are struggling to access foreign currency to enable production. Ndlovu-Gatsheni (2003: 128) argues that the economy will not 'be solved by populist rhetoric, devoid of pragmatism'. The question, therefore, is what it would take to fix the Zimbabwean problem. The question is dealt with in the next section.

\section{Fixing the Zimbabwean Problem}

Zimbabwe is endowed with a rich natural and human resource base that gives it an advantage over its regional and international counterparts (see Government of Zimbabwe 2013: 16). Bad governance that has given rise to political, economic and humanitarian problems requires urgent fixing, however (Ndlovu-Gatsheni 2003: 100). According to Smith (2007: 6), 
there are four sets of attributes that require reform if good governance is to be brought about: constitutional, political, administrative and public policy. He argues that at 'the constitutional level good governance requires changes that will strengthen the accountability of political leaders to the people, ensure respect for human rights, strengthen the rule of law, and decentralize political authority'. When it comes to political action and organisation, Smith states that 'three attributes of good governance are common to the governance agendas of most aid agencies; political pluralism, opportunities for extensive participation in politics, and probity and incorruptibility in the use of public powers and offices by servants of the state'. Turning to administration, he argues that 'good governance requires accountable and transparent public administration; effective public management, including a capacity to design good policies as well as to implement them'. In this section, we discuss six interventions that cut across these attributes and have the potential to make a positive impact on Zimbabwe.

\section{Building Trust and Confidence}

Public trust and confidence are key indicators of a functional government and good governance (Chanley et al. 2000: 239). When people have confidence in government institutions, they are more likely to support government policies, comply with the laws and pay taxes, among other responsibilities. In Zimbabwe, public trust and confidence in government institutions has been on a downward spiral in both the Mugabe and Mnangagwa era. The decline appears to be linked to people's disappointment in government, its inefficiency, ineffectiveness, inability to fight corruption, disputed elections, negative perceptions of the economy and an increase in their knowledge of how the government works, among other issues. In the ensuing paragraphs, we recommend reforms in democratic and administrative processes as some of the ways in which public trust and confidence can be restored.

\section{Democratic Processes}

Good governance denotes in part that governance processes, procedures and structures are democratic (Smith 2007: 4). The departure of Mugabe presents a real opportunity for the country to redeem public trust and confidence. One of the ways in which this can be achieved is by opening up political processes. This entails breaking from a past in which 
opposition politics was criminalised and frowned upon, and when those who led opposition endured harassment and intimidation, thereby closing the space for the democratic exchange of ideas. According to Osaghae (1999: 9), one of the crucial elements for assessing democratisation is the existence of pluralism and multipartyism. This relates to the existence of an environment that encourages competitive politics in which the opposition parties have a fair chance of coming to power. Although the political environment improved after the fall of Mugabe, the motivation for liberalisation is inadequate, in the sense that it appeared to have been pressured by external actors rather than being driven by a shared genuine desire for reform. Although external pressures are crucial for the establishment of democracy in countries previously under authoritarian rule, such pressures are motivated more by the need for such countries to entrench their interests (Smith 2007: 272). Thus, the desire to reform should be locally shared and driven, with international actors merely taking a supporting role. Reforms should, for instance, target institutions that administer elections or play a facilitative role in that regard, given that Zimbabwe has a long history of contested electoral processes and outcomes (Kambale (2012: 1; Rupiya 2012: 9; Southall and Slabbert 2018: 1). Public media reforms are also important in the context of enhancing democratisation and increasing public trust and confidence in government (African Network of Constitutional Lawyers 2012: 4). Finally, it has been observed that the reform of the Public Order and Security Act will go a long way towards fostering a healthy political environment, as the legislation tramples upon fundamental freedoms relating to association and assembly, among others, that are entrenched in the Constitution (Human Rights Watch 2013: 2). Politically, the legislation is out of sync with the pledge by Mnangagwa to do things differently.

\section{Administrative Processes}

Good governance is not only about democratic governance processes but also about efficient and effective administrative systems (Smith 2007: 4). Such systems were largely absent at all levels of government during the latter half of Mugabe's rule. Thus, it is crucial that the new government, post-Mugabe, should undertake extensive administrative reforms to improve efficiency and effectiveness. At the heart of the reforms is the need to refine the way in which government agencies work. This can be achieved by, among other things, professionalising human resource management, changing organisational structures and reviewing governance 
procedures. It is important that government agencies attract and retain public servants with the right skills, qualifications and dedication if service delivery is to improve. Professionalisation should be at the centre of the new recruitment and selection policy. Recruitment and selection should be preceded by rigorous job analysis (Ashraf 2017: 1). There is a need for the new administration to set up good succession planning in public service. Jarvalt (2007: 8) notes that viable succession planning needs to be accompanied by a training policy that motivates employees, heightens their organisational awareness, offers promotion opportunities, promotes common civil service culture and increases the skill base. The question of reducing the number of government employees will also need to be addressed, given that the civil service is bloated - to the extent that around $90 \%$ of the revenue collected by government goes towards meeting its salary obligations. The size of the civil service could be reduced by, among other strategies, eliminating ghost workers, verifying that civil servants on the payroll are actually working, laying off contract workers, voluntary retrenchments, early retirement, recruitment freezes and the closing of government agencies whose functions can be efficiently performed by the private sector (Lienert 1998: 6). To its credit, the Mnangagwa administration has already laid off a few senior government officials. These retrenchments, however, need to be based on performance evaluations and other verifiable considerations. Currently, it is hard to tell what the criteria for the retrenchments are, leading critics to speculate that they are targeting bureaucrats who are perceived to be sympathetic to Mugabe. The remuneration of government employees ought to be addressed as part of the administrative reforms. This entails reviewing the current remuneration policy, enhancing transparency and improving the ability of government to recruit and retain individuals with skills that are in short supply. A good remuneration policy needs to be guided by fiscal realities, competences, meritocracy, the penalisation of poor performers, the scarcity of certain skills and experience, and the elimination of salary gaps for comparable jobs; among other considerations (Lienert (1998: 7). It is also important that the efficiencies of government agencies are reviewed as part of the administrative reforms that are meant to improve service delivery. 


\section{Getting the Most Out of Limited Public Resources}

\section{Corruption}

In Zimbabwe, corruption is prevalent across all sectors, manifesting itself mainly through bribery, extortion, nepotism, patronage and grand venality, among other forms of abuse of power. The Corruption Index for 2018 ranked Zimbabwe 157 out of 176 countries which were surveyed. It is estimated that Zimbabwe is losing US\$1 billion annually to corruption to the detriment of economic and social development (Takawira 2017: 204). Corruption is harmful as it often increases the cost of doing business, dissuades foreign direct investment, distorts the financial and economic environment, undermines human capital development, creates inequalities in opportunities available to citizens and business actors, leads to inefficiencies in public service delivery and often results in poor allocation of resources, among other negatives (Mugova 2017: 1; Wafawarova 2015: 1). Thus, the fight against corruption is perhaps the biggest challenge confronting the post-Mugabe administration. The Zimbabwe AntiCorruption Commission (ZACC) faces a plethora of challenges that undermine its ability to fight corruption effectively. The challenges include political meddling, a lack of operational independence, the politicisation of corruption cases, a shortage of skilled staff and lack of sufficient resources. The National Prosecuting Authority (NPA), which prosecutes corrupt suspects, is grappling with similar challenges. In the first quarter of 2018, the Prosecutor-General issued a statement bemoaning the lack of political will, human capacity and financial support as the reasons most corruption cases were not being prosecuted (Hodzi 2018: 1). In response to the inability of the ZACC and NPA to contain corruption, President Mnangagwa established a special anti-corruption unit in his office responsible for investigating and prosecuting corruption cases. It remains to be seen whether this unit will bring dividends in the war against corruption.

Corruption in Zimbabwe is now so entrenched that only genuine anticorruption efforts anchored on key strategies have better prospects of containing it. A multi-actor and sectoral approach, whereby financial institutions, audit firms, anti-corruption agencies and tax authorities work in collaboration to prevent, detect, investigate and respond to corruption, is necessary. Without close collaboration and coordination between the agencies responsible for the identification, investigation and prosecution of corruption cases, the war against corruption is unlikely to be won any time soon. The recovery of proceeds of crime is an important aspect of 
anti-corruption initiatives throughout the world. There is, therefore, a need for Zimbabwe to set up or strengthen a specialist asset recovery agency responsible for tracing the proceeds of corruption, securing freezing orders, and confiscating and forfeiting assets. The courts play an important role of ensuring that those that steal from the poor are jailed. Currently, the judiciary faces a number of challenges that constrains its ability to deliver justice, such as lack of sufficient resources and corruption within its judicial ranks. Stiffer penalties for offenders can be an effective deterrent of corrupt behaviour. The existing penalties provided in law are not harsh enough to realise this objective. It has also not been uncommon for high-profile corrupt suspects or individuals to receive preferential treatment during investigation, prosecution and sentencing. There have been a number of arrests and prosecution of senior bureaucrats, politicians and other influential people in the post-Mugabe era, but the rate of arrests and prosecution does not mirror the deep state of corruption. The fact that there have been no significant successful prosecutions and that arrests and investigations are widely perceived to be selective continues to raise questions about the genuineness of anti-corruption efforts under the 'Second Republic' (Mahere 2019: 1).

\section{Resource Wastage}

The wastage of public resources is one of the challenges that the new administration needs to overcome. While an appetite for wasting resources is common throughout public services, including in state-owned enterprises and local government, it can be easily identified at high levels of government. President Mnangagwa has followed in the footsteps of Mugabe, whose cabinet was often criticised for being disproportionate to the size of the country and the state of the economy. On 8 November 2019, Mnangagwa announced the appointment of six new ministers and five new deputy ministers. At 25 ministers, 18 deputy ministers and 10 provincial ministers, the cabinet is now bigger than the one he inherited. He has also created an additional ministry (that of National Housing and Social Amenities). All ministries have permanent secretaries, principal directors, departmental directors and other senior staff, whose employment comes with hefty remuneration packages. Given that some of the ministries have identical responsibilities and functions, the duplication of roles and resource wastage is ubiquitous. The creation of non-essential top government positions, excess ministries and expendable departments is associated with a spike in travel and subsistence allowances, 
supererogatory travelling, unnecessary events and unimportant international travelling (Langa 2015: 1; Magaisa 2018a: 4). This resource wastage, which a struggling economy cannot bear, could be contained by making cabinet leaner, and abolishing unnecessary senior positions, ministries and departments. In addition, it would help to do away with unnecessary travel, reduce the number of delegates when travelling locally and abroad, and consume locally produced goods and services. It is also important that through its oversight function, parliament should hold the executive accountable for resource wastage, among other forms of unsound or uneconomic usage of resources.

\section{Public Procurement Process}

The public procurement process is one of the most critical governance process, in which development plans are translated into action in monetary terms. The importance of this process for national development in Zimbabwe is recognised in the 2013 Constitution, which requires that public funds be spent transparently, prudently, economically and effectively. Besides these general principles of public finance, the Constitution (section 315) requires the public procurement process to ensure that it is transparent, fair, honest, cost-effective and competitive. It singles out joint ventures, contracts for the construction and operation of infrastructure and facilities, and concessions for mineral and other rights as state contracts whose negotiation and performance requires strict regulation (see section $315(2)$ of the Constitution). This constitutional framework is there to ensure that Zimbabwe gets the most out of its public procurement processes. During the Lancaster House constitutional order, it was recognised that Zimbabwe did not always get the most out of its public procurement processes. More than six years into the new constitutional regime, the situation has not changed at all levels of government, and procurement is often being used to benefit a few key players, usually along political, social and economic lines (Chigudu 2014:21). The practice of contractors being paid for goods and services they have not delivered remains common. In other cases, some contractors provide substandard work and get paid for it, while others inflate prices above the market rates, usually in connivance with government officials. There is evidence of some contractors who have been given government contracts despite lacking the requisite capacity to deliver them. Thus, value for money has not been achieved in a significant number of contracts which have been awarded, and the overall implication is that a significant quantity of public funds 
continues to be lost through the public procurement process (Chigudu 2014: 23). Building a new Zimbabwe requires that there should be a change in how the public procurement process is utilised. If it is used for the public good, it has the potential to drive economic growth and social development.

\section{A Culture of Constitutionalism}

A new Zimbabwe needs a culture of constitutionalism, which is the centrepiece of any constitutional democracy, to develop. Constitutionalism requires the limitation of state power through a constitution or other mechanisms, to protect the citizens against arbitrary rule (Okoth-Ogendo 1993: 66). The key ingredients of constitutionalism are supremacy of the constitution, a Bill of Rights, separation of powers, democratic and accountable governance, independence of the judiciary and the rule of law. All these key principles of constitutionalism are captured in the 2013 Constitution of Zimbabwe. Thus, the foundation upon which a culture of constitutionalism can be built upon is already there. What is required is the creation of a conducive environment for this culture to thrive. While the full implementation of the Constitution is perhaps the starting point for the culture to develop, a change in political culture is essential given that the politics of independent Zimbabwe has been toxic.

\section{Rule of Law}

The starting point for setting Zimbabwe back on the right path is respect for the rule of law (Ndlovu-Gatsheni 2003: 129). This is important as the rule of law is the bedrock of any democratic society, which includes different dimensions of justice. The rule of law is a complex principle that requires the strict observance of constitutional and legislative rules, which can only flourish in an environment where the independence of the judiciary is protected and promoted. Gubbay (2016: 1) states that if a certain piece of legislation is required to give effect to a constitutional principle, goal or vision, such legislation should be enacted expeditiously, because without it that principle, goal or vision will not be realised. Once the relevant pieces of legislation are in place, he states that a climate of legality becomes important because without it laws are meaningless (Gubbay 2016: 1). The rule of law also requires an impartial and independent judiciary to oversee a legal framework that is known, clearly formulated, stable, predictable and applied uniformly. These principles provide a 'basis for 
"legitimate expectations" on the part of the citizens. The rule of law, thus, guarantee that citizens know what obligations are imposed by the law, and can expect these obligations to remain unchanged until the law is changed', but not in a retroactive manner (Smith 2007: 78). On the economic side, it is highly unlikely that an investor, especially an international one, will invest in a country where the legal framework is not predictable and respected, where the judiciary fails to implement the legislative framework fairly and where court decisions are not respected. Black markets, tax evasion and financial irregularities, which are common in Zimbabwe, are all symptoms of a market that lacks trust and confidence in the existing formal legal governance architecture. Thus, the rule of the law is not only important to protect and promote political rights but also economic development. In countries in transition such as Zimbabwe, the rule of the law is particularly crucial to 'help establish a clear break with the past, and new political culture in which all participants respects the law' (Smith 2007: 81).

\section{Respect for State Institutions}

Respect for state institutions is a fundamental feature in a constitutional democracy. Evidence in independent Zimbabwe, where the executive neutralised other arms of government, demonstrates that imbalance of power among the different arms of government is bad for democracy. The executive easily conducted its activities as it pleased with little or no oversight from other arms of government (Veritas 2016: 2). This unequal balance is one of the sources of many problems experienced after the first decade of independence. Modern constitutions are increasingly making provisions for independent constitutional commissions to strengthen democracy by, for example, complementing the role of the traditional arms of government. The 2013 Constitution of Zimbabwe, for instance, shares governmental power not just among the three arms of government (executive, parliament and judiciary), but also makes provision for the establishment of several independent commissions supporting democracy. The commissions include the Zimbabwe Human Rights Commission, Zimbabwe Gender Commission and the National Peace and Reconciliation Commission. The Constitution also makes provision for the Office of the Auditor General, ZACC and the NPA. It becomes important for these arms of government and constitutional bodies to respect each other's functional terrain while cooperating with one another to avoid repeating the mistakes of yesteryear. The decision of President Mnangagwa to 
establish a prosecutorial unit in his office has raised questions about whether the executive is not encroaching on the terrain of the NPA to the detriment of oversight. The same argument can be used in relation to the continued use of the President's power under the Presidential (Temporary Measures) Act to make law, an area reserved for parliament. Thus, respect for state institutions is necessary for a new Zimbabwe, otherwise it remains the old one.

\section{Redefining the Relationship Between the State and Its Citizens}

A new Zimbabwe is possible, but not without redefining the relationship between the state and its citizens. The state has obligations to its citizens inasmuch as the citizens have a role to play in a democratic society. The state is there to serve. It, therefore, follows that the delivery of public and social services to the people by the state is not a favour but an obligation. The relationship between the state, on one hand, and citizens, on the other hand, should be seen from the perspective of the fundamental human rights that are inalienable to every human being. Human rights 'are claims to entitlements that are held to be morally defensible regardless of the law in any particular sovereign state. Rights claim that others should act in a particular way, or refrain from acting in ways which restrict the enjoyment of what is claimed' (Smith 2007: 45). The respect, protection and promotion of human rights is a fundamental virtue of any democratic society (Smith 2007: 4). The state has a role to mediate relations between citizens to ensure that both individual and group rights are respected. Access to water, housing and sanitation are important socio-economic rights that should be protected and promoted by all tiers of government and their agencies as well as by constitutional bodies. The cholera outbreak of September 2018, which affected many and resulted in several deaths, shows that the government, at all levels, is failing to fulfil these rights. Yet the Constitution obliges the government to promote and protect these rights and to ensure that they are realised in practice. Thus, unless there are radical improvements in how the state delivers key public and social services, it will be a long time before a real new Zimbabwe can be realised.

\section{Economic Reforms}

Zimbabwe is in the grip of an economic crisis that has persisted for close to three decades. The crisis, which can be traced back to the Mugabe era, 
manifests among other aspects in high unemployment rate, liquidity challenges, a dwindling formal sector, corruption, heavy local and foreign debt, shortage of foreign currency and a lack of foreign direct investment. These problems have persisted in the 'Second Republic' under the Mnangagwa administration, dampening the euphoria and enthusiasm that accompanied Mugabe's ousting (Moulds 2017: 1). Economic reforms are necessary if the new administration wants to restore the country to its former glory as a regional economic powerhouse. Mnangagwa's Transitional Stabilisation Programme, an economic blueprint, carries a number of austerity measures to arrest some of the economic challenges. For instance, it provides measures to reduce the fiscal deficit, address debt challenges, and curb corruption and other rent-seeking behaviours (Government of Zimbabwe 2018: 11, 17, 18, 21). The economic reforms are yet to make a meaningful impact, partially because they lack effective implementation. The biggest culprit is the government, which continues to disrespect its own laws, policies and programmes. For instance, unbudgeted, unauthorised spending and overspending are still common (Mhlanga 2019: 1). The executive continues to spend resources outside the parameters approved by parliament. Such ill-disciplined fiscal behaviour has caused economic problems, such as hyperinflation, which have hit the poor the hardest in a country where unemployment is high and xtreme poverty is endemic. The absence of meaningful social safety nets exacerbates the plight of the poor. A number of factors need to be considered if economic reforms are to succeed, such as securing buy-in from ordinary citizens, opposition political formations, the business sector and the major international actors, including banks and other financial institutions. Furthermore, the government needs to address the contradictions in the ideologies underlying economic reforms. For example, although the country has pledged to liberalise the economy, key resource allocation systems remain centrally controlled, particularly by the executive. This could explain why efforts towards reforming the economy have thus far failed to deliver the desired dividends.

\section{Currency Reforms}

Zimbabwe has been operating a multicurrency regime, with the dominant currency being the US dollar since 2009. In 2016, the government introduced bond notes, a surrogate currency, with the stated objectives of incentivising exports, addressing cash shortages and preventing export of the US dollar at the expense of the local economy. The bond notes, which 
were said to be backed by hard currency under the Afreximbank facility, were pegged at $1: 1$ with the greenback. In short, the bond notes were said to be redeemable in exchange for US dollars. Initially, this arrangement worked until the government started to introduce more bond notes to the market to fund its expenditure (Magaisa 2018a: 3). Eventually, the bond notes lost value against the US dollar, resulting in the latter disappearing from formal channels and trading on the parallel market at high rates. In October 2018, the government introduced new monetary and tax regime measures, which included the provision of the opening of foreign currency accounts. These operated in parallel with the Real Transfer Gross System (RTGS)/bond notes accounts. On 24 June 2019, the government announced that foreign currency was no longer legal tender in Zimbabwe, making the RTGS dollar/bond notes the only acceptable medium of exchange for local transactions. On 7 November 2019, government announced that it was replacing the RTGS dollar with the Zimbabwe dollar. Although the country has tried to address the problem of shortage of foreign currency by banning local purchasers from using hard currency, the problem persists. Most local businesses and service providers have continued indexing prices to the US dollar. The situation is made worse by a lack of consistency in the application of the policy. For instance, the government has allowed mining companies and non-governmental organisations to continue doing business, including the payment of salaries, in US dollars. The government is also undermining its own policy. At ports of entry, the government policy that customs duty for car imports is made in US dollars and not the local currency has been retained. The adoption of about five currency regimes in less than three years shows that there is confusion and a lack of know-how. Unfortunately, the Zimbabwe dollar continues to lose value daily, impacting negatively on its buying power. The potential solution to the currency crisis that is unfolding lies in a full return to the multicurrency regime in which the Zimbabwe dollar has no role. This is required until the economic fundamentals are in place for the country to adopt its own currency. These include an increase in exports and therefore an improved ability to generate enough foreign currency to cover the country's major needs.

\section{Disposal of Non-Performing State-Owned Enterprises}

Zimbabwe has many state-owned enterprises (SOEs), established to advance government policy in areas such as the provision of public infrastructure and services such as water, energy, telecommunications, 
transportation, health and education, to mention just a few. Almost all SOEs have not performed well ever since the economic situation took a downturn. In 2016, for example, the Auditor General reported that 15 SOEs faced collapse as they were in untenable financial positions (2016: 2). The Zimbabwe Electricity Supply Authority and its subsidiaries, National Railways of Zimbabwe, Grain Marketing Board and TelOne were some of those that were reported to be on the brink of collapse owing to a deplorable financial situation (Majaka 2017: 1; Auditor-General 2016: 2). In the post-Mugabe era, the government needs to put in place policies that promote good corporate governance in these organisations. A critical part of realising this objective is ensuring that skills, competency and experience constitute the main basis upon which people are appointed to senior positions in these SOEs rather than patronage, as has been the preferred practice. Given this background, the new administration should also consider privatising some of the SOEs (Majaka 2017: 1).

\section{Investment}

There is no doubt that real economic development will not be realised in Zimbabwe unless there is tangible foreign direct investment. If the country is to attract investment, it is crucial that it reviews its investment policy, which under Mugabe was primarily anchored on the Look East policy. Adopted by Mugabe after western governments imposed restrictions on Zimbabwe, the policy seeks to expand bilateral and trade relations and offer priority to investors from the Far East countries. Chinyama (2015: 1) argues that the Look East policy often benefited China more than Zimbabwe, given that China has access to Zimbabwe's abundant natural resources at low cost. He further argues that most of the investments China made in Zimbabwe have not generated meaningful employment opportunities, as Chinese companies bring their own workers (Chinyama 2015: 1). Other concerns are that local employees are paid wages that are below those stipulated by the government and that Chinese companies do not often place premium on environmental impact assessment (Chinyama 2015: 1). As a result, many of the development projects established by the Chinese were undertaken at the expense of environmental preservation. Since Mugabe, President Mnangagwa has tried to reach out to western countries for investment. In this regard, he has sent ministerial delegations to engage with their governments and to participate in platforms for investment, such as the World Economic Forum. In addition, the Mnangagwa government has amended the Indigenisation and Economic 
Empowerment Act and adopted the motto 'Zimbabwe is Open for Business' in a bid to attract investment. Real investment has not been forthcoming despite all these spirited efforts, because the rhetoric has not translated into real action. Zimbabwe's human rights and rule of law records seem to be the major stumbling block. The disputed election of Mnangagwa has come with legitimacy deficiencies. Magaisa (2018b: 4) argues that Mnangagwa's administration needs to fix this deficit through engaging the opposition, particularly Nelson Chamisa's MDC, and undertaking serious political reforms. Without this, it is highly unlikely that investors will invest in Zimbabwe in the near future. While foreign investment is necessary, it is also important that the new administration improves the environment for local investment, as charity begins at home. For example, the new administration can promote local investment by reducing taxes, eliminating red tape in the approval of investment projects, reviewing the procedures for doing business and providing various incentives.

\section{The Stimulation of Local Production and the Role of the Reserve Bank}

Zimbabwe has been struggling to manage its imports bill, with imports significantly greater than exports. The implication is that more foreign currency goes, adversely affecting the balance of payments. To make matters worse, the majority of the imports are on consumption and not production goods and services. This means that the foreign currency is being spent on goods that do not generate additional foreign currency. As a result, the country the country is struggling to mobilise enough foreign currency to meet its needs. In the absence of sufficient foreign currency, the Reserve Bank of Zimbabwe (RBZ) has been allocating foreign currency to different sectors depending on priority considerations. The challenge is that some of the key sectors have not always been able to access the foreign currency they need to enable the production of goods and services. The result is often that there are shortages of certain goods and services which has a knock-on effect on price increases. The role of the $\mathrm{RBZ}$ in the allocation of foreign currency is also inefficient and provides room for rent-seeking. It is a mere attempt to address the symptom of the problem rather than being the long-term solution to foreign currency shortages - which lies with increasing local production and increasing exports (Magaisa 2018a: 3). Local production can be stimulated in various ways, including the provision of incentives to local industries. Until Zimbabwe begins to rely on its local industries, particularly for 
consumption goods, the balance of payments and therefore foreign currency shortages will remain a big problem. The role of the RBZ in quasifiscal activities is also problematic, and takes it away from its core function of setting monetary policy. Each time the bank is involved in quasi-fiscal activities, from the days of Mugabe when the RBZ Governor was Gideon Gono, the result has often been that the inflation rate increases and debt balloons, among other challenges. Unfortunately, those in power have turned a blind eye to this lesson from the past.

\section{Vertical Power-Sharing}

Like most post-colonial African governments, the ZANU-PF-led government inherited a system of government that concentrated governmental powers and resources at the centre. This centralisation of governmental powers continued as Zimbabwe walked into independence, giving rise to an over-centralised system of government. Hatchard et al. (2004: 20) contend that this system gave 'little or no space for alternative challenges, questions or control' at both vertical and horizontal levels. The responsiveness and accountability of the government were, therefore, compromised. The problems that Zimbabwe has experienced since 2000 can partially be attributed to the nature of this system. Building a new Zimbabwe will require the dismantling of this system and its replacement by a form of government in which governmental powers are shared at multiple levels. According to Manor (2013: 32), if this multilevel system of government is to work well, key ingredients must be in place. First, substantial powers must be devolved to democratic subnational units. Secondly, substantial resources must be devolved to subnational level. Thirdly, mechanisms that promote the horizontal accountability of bureaucrats to elected representatives as well as the downward accountability of elected representatives to the citizens are required. If these ingredients are in place, such a system of government has the potential to deliver development, democracy and peace (Chigwata 2018: 4-6).

\section{The Democratic Benefit}

Vertical power-sharing can deepen democracy in many ways. The organisation of government at multilevel levels creates multiple opportunities for political participation whether directly or through representatives (Smith 2007: 156). Citizens are likely to participate more when government is physically closer to them. Civil society activities are often 
stimulated when governmental powers and resources are injected into subnational and local arenas in order to influence decisions over the use of such resources (Manor 2013: 33). Smaller political parties and independent candidates, who often face difficulties in competing for political power at the national level, have a higher chance of succeeding at subnational and local level when the political costs of mobilisation tend to be low (Chigwata 2018: 5). The overall effect of this is that the democratic pluralism that lubricates a democratic society is promoted. Citizens are also more likely to hold public officials accountable at subnational or local level owing to the closer proximity of government. A multilevel system of government reduces the concentration of power at central level and the powers given to subnational governments can be effective in checking central government and preventing the arbitrary exercise of power (Hatchard et al. 2004: 187). This vertical separation of powers can go a long way towards complementing the horizontal separation of powers, involving the role of the judiciary, parliament and independent constitutional commissions (Chigwata 2018: 4-5). Thus, vertical power-sharing has the potential to enhance participatory, responsive and accountable governance in Zimbabwe.

\section{The Development Benefit}

Alongside its democratic benefits, vertical power-sharing also has the potential to engender development as public resources and power are diffused closer to the people. This enables the easier provision of public goods and services in line with local needs and preferences. The result is often that the government's responsiveness is improved (Manor 2013: 33). With decentralised governmental powers and resources, citizens in different parts of the country can define and lead their own developments. Some provinces are endowed with a variety of natural resources, yet the level of development in these provinces does not mirror this rich resource base. This imbalance can be attributed partially to the centralised approaches of exploiting natural resources, which have defined resource extraction and utilisation since independence at the expense of local communities. Real vertical power-sharing will ensure that local communities have direct access to the resources within their respective communities, so they can define their own development. Development projects led by the people themselves are likely to be more sustainable than those imposed by central government. Another benefit associated with vertical power-sharing is that it encourages competition, innovation and experimentation 
among subnational and local governments, which may result in the development of superior public policies that can make a positive impact on development objectives.

\section{Keeping the Nation Together}

For a while, Zimbabwe has been polarised primarily along political lines. This polarisation is beginning to adversely impact national integration and peace. Signs of one of the most dangerous forms of polarisation, ethnic polarisation, are also emerging. The key question is what will keep the national together. Vertical power-sharing can be a potential solution, given that it creates an environment that allows geographically concentrated groups to determine and shape those issues that immediately affect their lives (Chigwata 2018: 5). The potential for this is high in countries where ethnic groups are geographically concentrated in certain areas, such as Zimbabwe, where almost everyone has a province and local authority area that they call home. Most minority ethnic groups, such as the Ndebele, Venda and Tonga, are geographically concentrated in certain provinces, usually along border areas. Even the subethnic groups of the dominant Shona are geographically concentrated in certain areas. This concentration of ethnic groups, especially in border areas, increases the risk for secession. However, the potential for this can be neutralised by real vertical powersharing, which creates an environment where local interests can be accommodated 'within the stability of a strong central authority' (Hatchard et al. 2004: 185). The resultant multilevel system of government prevents a winner takes all situation, since political power can still be exercised not just at national but also at subnational and local levels (Manor 2013: 33). Vertical power-sharing has a high chance of accommodating a diversity of interests. Thus, governmental powers and resources should be diffused not only to subnational governments but also to the people.

Lessons from the past show that Zimbabwe needs to do away with an over-centralised system of government. The big advantage is that the 2013 Constitution, while not perfect, provides a foundation upon which a devolved system of government can be built. This shift towards a devolved system of government is premised on the fundamental belief that once they are entrusted with their own destiny through the medium of popular local democratic institutions, human beings can govern themselves in peace and dignity in pursuit of their collective well-being' (Hatchard et al. 2004: 185). Zimbabwe has much to gain if it adopts a devolved system of government which can be accommodated in a unitary form of 
government. It should, however, be acknowledged that a multilevel system of government requires significant state capacity, which is currently not available (see Manor 2013: 32). Nevertheless, the absence of significant state capacity should not be the reason why centralisation should be adopted, as a capacity-building process can run parallel to the process of devolution.

\section{International Integration}

Ever since Zimbabwe embarked on the Fast Track Land Reform Programme in the early 2000 s, its relations with multilateral institutions and western countries have been sour. It has defaulted on several of its debt obligations. The country has isolated itself from the west preferring to engage with the east. As a result, and unlike some of its African counterparts, Zimbabwe has not been able to access financial support from the multilateral institutions and to attract significant budgetary support from the western countries. Yet the country badly needs a cash injection to stimulate its faltering economy. Ndlovu-Gatsheni (2003: 128) argues that '[i]n this century of globalisation, it is impossible for any nation, including the developed West, to try and isolate itself even in a "splendid isolation" fashion from the complex web and framework of the international community'. Even the eastern countries that Zimbabwe has been dealing with for the past two decades do business with the west. Zimbabwe does not have the luxury to choose which countries to deal with given its precarious economic situation. Thus, 'the way forward for Zimbabwe lies in returning to the diplomatic chessboard and to bargain from within, rather than to adopt a belligerent stance against the international community' (Ndlovu-Gatsheni 2003: 129). Zimbabwe has no choice but to reenter the international family of nations by normalising relations with multilateral institutions and the west. The settling of debt obligations and improving its human rights record are some of the many measures that can have a positive impact on Zimbabwe's relations with international actors.

\section{Conclusion}

Zimbabwe has experienced several decades of political and economic challenges that can largely be attributed to the political and economic choices of the ruling elites. Very few in the ruling ZANU-PF or close to the party are willing to acknowledge their role in or take the blame for Zimbabwe's 
economic and political crisis. Some of them attribute the economic crisis to sanctions or restrictions imposed on Zimbabwe by the west, thereby choosing to ignore the impact of corruption and mismanagement, among other ills, that have bedevilled the country for several decades. The country is endowed with rich resources, both natural and human, that are needed to reboot economic development. In 2013, Zimbabwe adopted a new Constitution that is progressive in many respects and provides a foundation for Zimbabwe to move forward. According to Ndlovu-Gatsheni ( 2003: 129) What the country has been lacking is 'a flexible, malleable and visionary leadership capable of charting a new dispensation not clouded in bankrupt ideologies, but consonant with the prevailing local, regional and international developments'. The fall of Robert Mugabe in November 2017 provided an opportunity for the country to break from its ugly past and set a new development path. Mugabe's successor, Emmerson Mnangagwa, announced himself on the international stage as a reformist willing to change the political and economic course that has led the former bread basket of Southern Africa to a basket case. He announced the birth of a 'Second Republic' characterised by clean governance, an open business environment and widened scope for the exercise of fundamental human rights and freedoms. The change process has, however, been slow and painful, making it indistinguishable from the old dispensation. Unless the new administration begins to walk the talk of change, Zimbabwe will remain a basket case. What is required is a governance culture where political, private and individual interests do not thrive at the expense of the public good.

\section{REFERENCES}

ANCL. 2012. National Study on Access to Information in Zimbabwe, Department of Public Law, University of Cape Town, 1-60.

Ashraf, J. 2017. Examining the Public Sector Recruitment and Selection, in Relation to Job Analysis in Pakistan. Journal of Cogent Social Sciences 3 (1): $1-11$.

Auditor-General. 2016. AG Report 2015 on Parastatals and State Enterprises. At https://www.auditorgeneral.gov.zw/downloads/category/2-parastatals. Accessed 24 Nov 2019.

Bourne, R. 2011. Catastrophe: What Went Wrong in Zimbabwe? London: Zed Books. 
Chanley, V.A., T.J. Rudolf, and W.M. Rahn. 2000. The Origins and Consequences of Public Trust in Government: A Time Series Analysis. Public Opinion Quarterly 64: 239-256.

Chigudu, D. 2014. Public Procurement in Zimbabwe: Issues and Challenges. Journal of Governance and Regulation 3 (4): 21-26.

Chigwata, T.C. 2018. Provincial and Local Government Reform in Zimbabwe: An Analysis of the Law, Policy and Practice. Cape Town: Juta.

Chinyama, G. 2015. Look East Policy Remains a Mirage. Available at https:// www.thestandard.co.zw/2015/02/15/look-east-policy-remains-mirage/. Accessed 7 Nov 2019.

Chirimambowa, T.C. 2016. Succession Politics in Zimbabwe: Grace Mugabe and the End of the Patriotic History. At http://www.salo.org.za/wp-content/ uploads/2015/02/DOlof20161.pdf. Accessed 20 Nov 2019.

Government of Zimbabwe. 2013. Zimbabwe Agenda for Sustainable SocioEconomic Transformation (ZimAsset) “Towards an Empowered Society and a Growing Economy”, October 2013-December 2018.

Government of Zimbabwe Transitional Stabilisation Programme Reforms Agenda. 2018 October-2020 December. Towards a Prosperous \& Empowered Upper Middle Income. Society by 2030, Harare, 5 October 2018.

Gubbay, A.R. 2016. The Progressive Erosion of the Rule of Law in Independent Zimbabwe. The Third International Rule of Law Lecture: The Bar of England and Wales. 9 December 2009. 1. http://www.barcouncil.org.uk/ media/100365/rule_of_law_lecture_agubbay_091209.pdf. Accessed 24 Nov 2019.

Hatchard, J., et al. 2004. Comparative Constitutionalism and Good Governance in the Commonwealth: An Eastern and Southern African Perspective. Cambridge: University Press.

Hodzi, K. 2018. The Prosecutor General's Speech (Guest of Honour) at the Occassion of the Mutare Anti-Corruption Commission Court. https://jsc.org.zw/jscbackend/upload/Publications/prosecutor $\% 20$ general\%20speech.pdf. Accessed 8 July 2020.

Huffington Post. 2017. Reports-Military Coup Is Underway in Zimbabwe. At https://www.huffingtonpost.co.za/2017/11/14/reports-military-coup-isunderway-in-zimbabwe_a_23276882/. Accessed 17 June 2018.

Human Rights Watch. 2013. Race Against Time: The Need for Legal and Institutional Reforms Ahead of Zimbabwe's Elections. Washington, DC: Human Rights Watch.

Jarvalt, J. 2007. What Does Professionalisation of Public Service Mean to Estonian Top Officials? Paper presented at the University of Tartu, Estonia.

Jongwe, F. 2018. Ex-Zimbabwe Leader Mugabe Calls Ouster 'Coup de'tat'. At https://citizen.co.za/news/news-africa/1857953/zimbabwe-politicsmugabe-politics/. Accessed 25 Oct 2019. 
Jordan, N. 2017. This Is a Historic Moment for Zimbabwe. At https://www. timeslive.co.za/news/africa/2017-11-15-this-is-an-historic-moment-for-zimbabwe/. Accessed 17 Oct 2019.

Kabemba, C. 2004. An Assessment of Zimbabwe's Election Administration. In Negotiating the Impasse: Challenges and Prospects for Democratisation in Zimbabwe, ed. W. Olaleye. Johannesburg: EISA.

Kambale, P. 2012. The Contribution of Electoral Management Bodies to Credible Elections in West Africa. In Electoral Management Bodies in West Africa: A Comparative Study of the Contribution of Electoral Commissions to the Strengthening of Democracy, ed. I. Madior Fall et al. Johannesburg: Open Society Foundations.

Kwaramba, F. 2017. Army to Decide Mugabe Successor. At https://www.dailynews.co.zw/articles/2017/07/23/army-to-decide-mugabe-successor. Accessed 17 Aug 2019.

Langa, V. 2015. Mugabe's Bloated Cabinet Blamed for Cash Crunch. At https:// www.thestandard.co.zw/2015/12/20/mugabes-bloated-cabinet-blamed-forcash-crunch/. Accessed 18 Nov 2019.

Lienert, L. 1998. Civil Service Reform in Africa Mixed Results After 10 Years. Available at http://unpanl.un.org/intradoc/groups/public/documents/ CAFRAD/UNPAN010695.pdf. Accessed 12 Sept 2018.

Mabaye, T.M. 2005. Land Reform in Zimbabwe: An Examination of Past and Present Policy, Shortcomings and Successes and Recommendations for Improvement. At https://web.stanford.edu/class/e297a/Land\%20 Reform\%20in\%20Zimbabwe.doc. Accessed I Dec 2019.

Magaisa, A. 2018a. Big Saturday Read: Mending a Broken Economy. alexmagaisa. com. Published 15 Sept 2018.

- 2018b. Big Saturday Read: Mnangagwa-Political Reformer or Master of Tokenism. alexmagaisa.com. Published 29 Sept 2018.

Mahere, F. 2019. We Were Promised Change - But Corruption and Brutality Still Rule in Zimbabwe. Available at https://www.theguardian.com/commentisfree/2019/aug/19/corruption-brutality-zimbabwe-emmerson-mnangagwaprotesters. Accessed 20 Nov 2019.

Majaka, N. 2017. 15 Parastatals Face Collapse. Available at https://www.dailynews.co.zw/articles/2017/06/27/15-parastatals-face-collapse. Accessed 2 Dec 2019.

Manor, J. 2013. Understanding Decentralisation: Key Issues for Successful Design. In The Imperative of Good Local Governance: Challenges for the Next Decade of Decentralisation, ed. J. Ojendal and A. Dellnas. New York: United Nations University Press.

Marumahoko, S. 2018. The Constitutional Processes in Kenya and Zimbabwe: A Comparative Perspective. Strategic Review of Southern Africa 40 (2): 16-33. 
Mbizwo, A. 2017. Zimbabwe's Mnangagwa Appoints Army Boss as ZANUPF Vice President. At https://www.huffingtonpost.co.za/2017/12/23/ zimbabwes-mnangagwa-appoints-former-army-boss-as-ZANU-PF-vicepresident_a_23315847/. Accessed 18 Nov 2019.

Mhlanga, B. 2019. Govt Squanders US\$10,6 Billion. At https://www.newsday. co.zw/2019/11/govt-squanders-us106-billion/. Accessed 20 Nov 2019.

Moulds, J. 2017. These Charts Show the Economic Challenges Facing Zimbabwe Post-Mugabe. Available at https://www.weforum.org/agenda/2017/11/ these-charts-show-the-economic-challenges-facing-zimbabwe-post-mugabe/. Accessed 19 Sept 2019.

Mugova, S. 2017. The Impact of Corruption and Lost 15 Billion on Zimbabwe's Economy. Available at https://www.news24.com/MyNews24/the-impact-ofcorruption-and-lost-15-billion-on-zimbabwes-economy-20170321. Accessed on 10 Nov 2019.

Muzondidya, J. 2009. From Buoyancy to Crisis, 1980-1987. In Becoming Zimbabwe: A History from the Pre-Colonial Period to 2008, eds. B, Raftopoulos and A. Mlambo. Harare: Weaver Press.

Ndlovu-Gatsheni, S. 2003. Dynamics of the Zimbabwe Crisis in the 21st Century. African Journal on Conflict Resolution - ACCORD 2003/1: 99-134.

Newsday. 2012. We Have Failed to Run Parastatals. At https://www.newsday. co.zw/2012/07/2012-07-04-we-have-failed-to-run-parastatals/. Accessed 15 Aug 2019.

Okoth-Ogendo, H.W.O. 1993. Constitutions Without Constitutionalism: Reflections on an African Political Paradox. In Constitutionalism and Democracy, Transitions in the Contemporary World, ed. D. Greenberg, S. Katz, M. Oliviero, and S. Wheatley. Oxford: OxfordUuniversity Press.

Osaghae, E. 1999. Democratisation in Sub-Saharan Africa: Faltering Proposals, New Hopes. Journal of Contemporary African Studies 17 (1): 5-24.

Raftopoulos, B. 2009. The Crisis in Zimbabwe, 1998-2008. In Becoming Zimbabwe: A History from the Pre-Colonial Period to 2008, eds. B, Raftopoulos and A. Mlambo. Harare: Weaver Press.

Rupiya, B. 2012. The Military Factor in Zimbabwe's Political and Electoral Affairs. At http://www.swradioafrica.com/Documents/The\%20Military\%20 Factor\%20in\%20Zimbabwe.pdf. Accessed 17 Sept 2019.

Samaita, K. 2019. Zimbabwe Fires 211 Doctors and Hires New Ministers. At https://www.businesslive.co.za/bd/world/africa/2019-11-10-zimbabwefires-211-doctors-and-hires-new-ministers/. Accessed 2 Dec 2019.

Smith, B.C. 2007. Good Governance and Development. New York: Palgrave Macmillan.

Southall, R., and V.Z. Slabbert. 2018. How and Why ZANU-PF Won the 2013 Elections. Strategic Review for Southern Africa 35 (2): 135-151. 
Takawira, T. 2017. Corruption and Bad Policies Repel Foreign Capital and Cause Domestic Capital to Flee: Is Jovanovic Right? International Journal of Economics and Financial Issues 7 (5): 204-215.

The Institute for Social Accountability. 2012. Oversight Role of Parliament. Nairobi: The Institute of Social Accountability.

The World Bank and the United Nations Office of Drugs and Crimes. 2009. Stolen Asset Recovery: Towards a Global Architecture for Asset Recovery. A Policy Note Will Be Presented as a Consultative Draft at the United Nations Convention Against Corruption Third Conference of States Parties Held in Doha, Qatar, from 9-13 November 2009.

Veritas. 2016. Executive Powers. Available at http://www.veritaszim.net/ node/2074. Accessed 21 Nov 2019.

Vines, A. 2017. What Is the Extent of China's Influence in Zimbabwe? Available at https://www.bbc.com/news/world-africa-42012629. Accessed 19 Sept 2019.

VOA. 2017. Even After Ouster, Zimbabwe's Mugabe Hogs the Headlines. At https://www.voazimbabwe.com/a/robert-mugabe-interview-utterances/4303256.html. Accessed 18 Aug 2019.

Wafawarova, R. 2015. Anti-Corruption-Reality or Rhetoric. At https://www.herald.co.zw/anti-corruption-reality-or-rhetoric/. Accessed 18 Nov 2019. 